\title{
Integrated Management of Stem and Root Rot of Sesame (Sesamum indicum L.) caused by Macrophomina phaseolina (Tassi) Goid
}

\author{
Nayan Kishor Adhikary ${ }^{1 *}$, Md. Riton Chowdhury ${ }^{1}$, \\ Tamina Begum ${ }^{1}$ and Rambilash Mallick ${ }^{2}$
}

\begin{abstract}
${ }^{1}$ ICAR-All India Coordinated Research Project on Sesame and Niger, ${ }^{2}$ Department of Agronomy, Institute of Agricultural Science, University of Calcutta, 51/2, Hazra Road, Kolkata-700019, India
\end{abstract}

*Corresponding author

\section{A B S T R A C T}

\section{Ke ywords}

Sesame, Stem and root rot,

Macrophomina

phaseolina,

Incidence,

Management

Article Info

Accepted:

07 March 2019

Available Online:

10 April 2019
Sesame (Sesamum indicum L.) is one of the most ancient oil seed crop cultivated in tropical and sub-tropical countries. Irrespective of the agro-climate conditions, sesame is liable to be infected by various pathogenic fungi. Among the fungal diseases, stem and root rot of sesame caused by Macrophomina phaseolina affects severely at all stages of crop growth. Macrophomina phaseolina is a diverse, omnipresent soil borne pathogen. The pathogen survives as sclerotia in the soil and in host tissue for varying periods. Two consecutive summer season trials of 2017 and 2018 were conducted at Agricultural Experimental Farm, Institute of Agricultural Science, University of Calcutta, Baruipur, South 24 Parganas. Integrated management of stem and root rot disease (M. phaseolina) of sesame was conducted with seven treatments. The results revealed that minimum stem and root rot incidence $(9.5 \%)$ and maximum yield $(557 \mathrm{~kg} / \mathrm{ha})$ with $\mathrm{C}: \mathrm{B}$ ratio 2.40 in 2017, stem and root rot incidence $(10.5 \%)$ and Maximum yield $(545 \mathrm{~kg} / \mathrm{ha})$ with $\mathrm{C}: \mathrm{B}$ ratio 2.33 in 2018 were recorded in the treatment of T6 (Seed treatment with carbendazim @ $2 \mathrm{~g} / \mathrm{kg}$ + soil drenching with carbendazim @ $1 \mathrm{~g} / 1)$.

\section{Introduction}

Sesame (Sesamum indicum L.) rhetorical as "Queen of oilseeds" is one of the most important ancient edible oilseed crop grown in India. Among the oilseed crops, sesame ranks first for its higher oil content with 6335 $\mathrm{kcal} \mathrm{kg}^{-1}$ of dietary energy in seeds (Kumar and Goel, 1994). Oilseeds are among the major crops that are grown in the country apart from cereals. India contributes the highest sesame acreage of above 17.73 lakh hectare and production 8 lakh tones and productivity of $445 \mathrm{~kg} / \mathrm{ha}$. The low productivity is attributed to poor crop management and exposure of the crop to a number of biotic and abiotic stresses. India is the fifth largest vegetable oil economy in the world, next only to USA, China, Brazil and Argentina and has an annual turnover of about 
Rs. 80,000 crore. India accounts for $12-15 \%$ of oilseeds area, $7-8 \%$ of oilseeds production, $6-7 \%$ of vegetable oils production, $9-12 \%$ of vegetable oils import and 9-10\% of edible oils consumption (Jha et al., 2014). Sesame seed is a rich source of protein $(20 \%)$ and edible oil $(50 \%)$ and contains about $47 \%$ oleic acid and 39\% linolenic acid (Shyu and Hwang, 2002). Sesame oil has excellent stability due to the presence of the natural antioxidants sesamoline, sesamin and sesamol.

The area and production of sesame crop is declining in the traditional areas. Despite the potential for increasing the production and productivity of sesame, there are a number of challenges inhibiting sesame production and productivity.

The main reason for low productivity of this crop is due to the attack of various fungal, bacterial and viral diseases. About 72 fungi, 7 bacteria, 1 phytoplasmal and 1 viral disease have been reported from India (Vyas et al., 1984). Out of these, about 32 diseases (14 major and 18 minor) occur in India. The crop is susceptible to number of fungal diseases, such as Charcoal rot of sesame ( $M$. phaseolina), Alternaria leaf spot (Alternaria sesami), Powdery mildew (Erysiphe cichoracearum) and Cercospora leaf spot (Cercospora sesami). Among the fungal diseases, Charcoal rot caused by $M$. phaseolina affects severely at all stages of the crop growth. The disease is particularly reported to be quite serious, limiting the production of crop. High temperature and water stress during growing season favours the pathogen's incidence. Vyas, (1981) reported $M$. phaseolina as very serious and destructive pathogen in all sesame growing areas and causes $5-100 \%$ yield loss while Maiti et al., (1988) estimated yield loss of around $57 \%$ at about $40 \%$ of disease incidence. Murugesan et al., (1978) observed
$1.8 \mathrm{~kg}$ yield loss per hectare at every one percent increase in disease intensity.

At present chemical fungicides are the first choice to combat diseases because of their easy adaptability and immediate therapy. Due to health risk and pollution hazards by use of chemical fungicides in plant disease control, it is considered appropriate to minimize their use. Since sesame seed and oil are in high demand for export due to their high unsaturated fat and methionine content, focus has been shifted out safer alternatives to chemical fungicides in recent years. Biological control had attained importance in modern agriculture to limit the hazards of intensive use of chemicals for disease control. Since the efficacy of biocontrol agents in disease attenuation has been inappropriate due to their inability to maintain a critical threshold population necessary for sustained biocontrol activity, biocontrol with antagonistic microorganisms alone could not be a complete replacement for management strategies currently employed. To enhance and extend the desired response, the addition of specific substrates which are utilized selectively by the introduced microbe employed as biocontrol agent (Paulitz, 2000).

Therefore integrated management that incorporates the biocontrol agents, botanicals and organic amendments would reduce the amount of fungicide used per season in addition to combat diseases in an economically viable and ecologically safe proportion.

No much research work is carried out particularly stem and root rot of sesame disease in West Bengal. Hence, an attempt was undertaken to assess the effect of integrated disease management with different treatments in respect of disease incidence and yield of sesame. 


\section{Materials and Methods}

Two consecutive summer season trials of 2017 and 2018 were laid down at Agricultural Experimental Farm, Baruipur, South 24 Parganas, Institute of Agricultural Science, University of Calcutta with seven treatments in integrated manner, $\mathrm{T}_{1:}$ Seed treatment with T. viride@ $4 \mathrm{~g} / \mathrm{kg}+$ soil application of $T$. viride@2.5 kg/ha enriched in $100 \mathrm{~kg}$ of FYM at sowing; $\mathrm{T}_{2:}$ Seed treatment with $P$. Flourescens@10 g/kg + Soil application of P.fluorescens @ $2.5 \mathrm{~kg} / \mathrm{ha}$ enriched in $100 \mathrm{~kg}$ of FYM at sowing; $\mathrm{T}_{3}$ : Seed treatment with $T$. viride @ $4 \mathrm{~g} / \mathrm{kg}+$ soil application of T. viride @ $2.5 \mathrm{~kg} / \mathrm{ha}$ enriched in $100 \mathrm{~kg}$ of FYM + neem cake @ $250 \mathrm{~kg} / \mathrm{ha}$ at sowing; $\mathrm{T}_{4}$ : Seed treatment with P. fluorescens @ $10 \mathrm{~g} / \mathrm{kg}+$ soil application of $P$. fluorescens @ $2.5 \mathrm{~kg} / \mathrm{ha}$ enriched in $100 \mathrm{~kg}$ of FYM + neem cake 250 $\mathrm{kg} / \mathrm{ha}$ at sowing; $\mathrm{T}_{5}$ : Seed treatment with $T$. viride + P. fluorescens @ $10 \mathrm{~g} / \mathrm{kg}+$ Soil application of $P$. fluorescens @ $2.5 \mathrm{~kg} / \mathrm{ha}+T$. viride@2.5 kg/ha enriched in $100 \mathrm{~kg}$ of FYM + neem cake@ 250 kg/ha at sowing; $\mathrm{T}_{6:}$ Seed treatment with carbendazim @2 $\mathrm{g} / \mathrm{kg}+$ soil drenching with carbendazim @ 1 $\mathrm{g} / \mathrm{l}$ and $\mathrm{T}_{7}$ : Untreated check (control) in randomized block design with three replications. The incidence of Macrophomina root rot was recorded individually by counting the number of affected and healthy plants at random quadrate selection in each plot and the percent incidence was calculated. The grain yield was recorded and C:B ratio was worked out.

\section{Results and Discussion}

Stem and root rot are caused by $M$. phaseolina (Tassi) Goid (Mihail, 1995). The symptoms were produced at ground level stem becomes black, which extends upward rupturing the stem and black dots appear on the infected stem.

Table.1 Integrated management of stem and root rot disease of sesame caused by M. phaseolina during summer, 2017

\begin{tabular}{|c|c|c|c|}
\hline Treatment & $\begin{array}{l}\text { Stem and Root } \\
\text { rot }(\%)\end{array}$ & $\begin{array}{c}\text { Yield } \\
(\mathrm{Kg} / \mathrm{ha})\end{array}$ & C:Bratio \\
\hline $\begin{array}{l}\mathrm{T}_{1} \text { : Seed treatment with } T \text {. viride @ } 4 \mathrm{~g} / \mathrm{kg}+\text { soil application of } T \text {. } \\
\text { viride @ } 2.5 \mathrm{~kg} / \mathrm{ha} \text { enriched in } 100 \mathrm{~kg} \text { of FYM at sowing. }\end{array}$ & $26.3(31.16)$ & 291 & 1.25 \\
\hline $\begin{array}{l}\mathrm{T}_{2} \text { : Seed treatment with } P \text {. flourescens @ } 10 \mathrm{~g} / \mathrm{kg}+\text { Soil application } \\
\text { of } P \text {. fluorescens @ } 2.5 \mathrm{~kg} / \mathrm{ha} \text { enriched in } 100 \mathrm{~kg} \text { of FYM at sowing. }\end{array}$ & $16.6(24.22)$ & 438 & 1.89 \\
\hline $\begin{array}{l}\mathrm{T}_{3} \text { : Seed treatment with } T . \text { viride @ } 4 \mathrm{~g} / \mathrm{kg}+\text { soil application of } T \text {. } \\
\text { viride @ } 2.5 \mathrm{~kg} / \mathrm{ha} \text { enriched in } 100 \mathrm{~kg} \text { of FYM + neem cake @ } 250 \\
\mathrm{~kg} / \mathrm{ha} \text { at sowing. }\end{array}$ & $12.5(21.11)$ & 479 & 2.06 \\
\hline $\begin{array}{l}\mathrm{T}_{4} \text { : Seed treatment with } P . \text { fluorescens @ } 10 \mathrm{~g} / \mathrm{kg}+\text { soil application } \\
\text { of } P . \text { fluorescens @ } 2.5 \mathrm{~kg} / \mathrm{ha} \text { enriched in } 100 \mathrm{~kg} \text { of FYM + neem } \\
\text { cake } 250 \mathrm{~kg} / \mathrm{ha} \text { at sowing. }\end{array}$ & $21.8(27.98)$ & 364 & 1.57 \\
\hline $\begin{array}{l}\mathrm{T}_{5} \text { : Seed treatment with } T \text {. viride }+P \text {. fluorescens @ } 10 \mathrm{~g} / \mathrm{kg}+\mathrm{soil} \\
\text { application of } P . \text { fluorescens @ } 2.5 \mathrm{~kg} / \mathrm{ha}+T . \text { viride @ } 2.5 \mathrm{~kg} / \mathrm{ha} \\
\text { enriched in } 100 \mathrm{~kg} \text { of FYM + neem cake @ } 250 \mathrm{~kg} / \mathrm{ha} \text { at sowing. }\end{array}$ & $11.2(19.79)$ & 532 & 2.29 \\
\hline $\begin{array}{l}\mathrm{T}_{6} \text { : Seed treatment with carbendazim @ } 2 \mathrm{~g} / \mathrm{kg}+\text { soil drenching } \\
\text { with carbendazim @ } 1 \mathrm{~g} / \mathrm{l} \text {. }\end{array}$ & $9.5(18.34)$ & 557 & 2.40 \\
\hline $\mathbf{T}_{7}$ : Untreated check & $33.6(35.56)$ & 254 & \\
\hline S.Em \pm & 1.64 & 4.59 & \\
\hline CD $(5 \%)$ & 5.07 & 14.14 & \\
\hline
\end{tabular}

*Figures in parenthesis are angular transformed values 
Table.2 Integrated management of root rot disease of sesame caused by M. phaseolina during summer, 2018

\begin{tabular}{|c|c|c|c|}
\hline Treatment & Root $\operatorname{rot}(\%)$ & Yield (kg/ha) & C:B ratio \\
\hline $\begin{array}{l}T_{1} \text { : Seed treatment with } T \text {. viride @ } 4 \mathrm{~g} / \mathrm{kg}+\text { soil application } \\
\text { of } T \text {. viride @ } 2.5 \mathrm{~kg} / \mathrm{ha} \text { enriched in } 100 \mathrm{~kg} \text { of FYM at sowing. }\end{array}$ & $\begin{array}{c}34.5 \\
(36.26)\end{array}$ & 277 & 1.23 \\
\hline $\begin{array}{l}\mathrm{T}_{2}: \text { Seed treatmen twith } P . \text { flourescens @ } 10 \mathrm{~g} / \mathrm{kg}+\text { Soil } \\
\text { application of } P \text {. fluorescens } @ 2.5 \mathrm{~kg} / \mathrm{ha} \text { enriched in } 100 \mathrm{~kg} \text { of } \\
\text { FYM at sowing. }\end{array}$ & $\begin{array}{c}23.3 \\
(28.70)\end{array}$ & 434 & 1.89 \\
\hline $\begin{array}{l}\mathrm{T}_{3} \text { : Seed treatment with } T . \text { viride @ } 4 \mathrm{~g} / \mathrm{kg}+\text { soil application } \\
\text { of } T . \text { viride @ } 2.5 \mathrm{~kg} / \mathrm{ha} \text { enriched in } 100 \mathrm{~kg} \text { of } \mathrm{FYM}+\text { neem } \\
\text { cake @ } 250 \mathrm{~kg} / \mathrm{ha} \text { at sowing. }\end{array}$ & $\begin{array}{c}15.8 \\
(23.54)\end{array}$ & 482 & 2.10 \\
\hline $\begin{array}{l}T_{4} \text { : Seed treatment with } P . \text { fluorescens @ } 10 \mathrm{~g} / \mathrm{kg}+\text { soil } \\
\text { application of } P . \text { fluorescens @ } 2.5 \mathrm{~kg} / \mathrm{ha} \text { enriched in } 100 \mathrm{~kg} \text { of } \\
\text { FYM + neem cake } 250 \mathrm{~kg} / \mathrm{ha} \text { at sowing. }\end{array}$ & $\begin{array}{c}26.5 \\
(30.94)\end{array}$ & 358 & 1.55 \\
\hline $\begin{array}{l}\mathrm{T}_{5}: \text { Seed treatment with } T . \text { viride }+P . \text { fluorescens @ } 10 \mathrm{~g} / \mathrm{kg}+ \\
\text { Soil application of } P . \text { fluorescens @ } 2.5 \mathrm{~kg} / \mathrm{ha}+T . \text { viride @ } 2.5 \\
\mathrm{~kg} / \mathrm{ha} \text { enriched in } 100 \mathrm{~kg} \text { of FYM + neem cake @ } 250 \mathrm{~kg} / \mathrm{ha} \text { at } \\
\text { sowing. }\end{array}$ & $\begin{array}{c}13.2 \\
(21.66)\end{array}$ & 526 & 2.27 \\
\hline $\begin{array}{l}\mathrm{T}_{6} \text { : Seed treatmentwith carbendazim @ } 2 \mathrm{~g} / \mathrm{kg}+\text { soil } \\
\text { drenching with carbendazim @ } 1 \mathrm{~g} / \mathrm{l} \text {. }\end{array}$ & $\begin{array}{c}10.8 \\
(19.59)\end{array}$ & 545 & 2.33 \\
\hline $\mathbf{T}_{7}:$ Untreated check & $\begin{array}{c}39.2 \\
(38.87)\end{array}$ & 246 & \\
\hline S.Em \pm & 2.88 & 4.39 & \\
\hline CD (5\%) & 8.86 & 13.53 & \\
\hline
\end{tabular}

*Figures in parenthesis are angular transformed values

It is evident from the table 1 that all treatments were found to be superior over untreated check $\left(\mathrm{T}_{7}\right)$ in reducing the disease incidence and increasing grain yield and $\mathrm{C}: \mathrm{B}$ ratio during summer, 2017. Of which, $\mathrm{T}_{6}$ including the seed treatment with carbendazim @2 g/kg + soil drenching with carbendazim @ $1 \mathrm{~g} / \mathrm{l}$ was found to be significantly effective by recording the minimum incidence of stem and root rot $(9.5 \%)$ and higher yield $(557 \mathrm{~kg} / \mathrm{ha})$ during summer, 2017.This result is confirmed by the finding of Chauhan (1988) who observed good control of $M$. Phaseolina by seed treatment with carbendazim. A similar observation also made by Shumaila and Khan (2016).

The results exhibited in the table 2, low disease incidence $(10.8 \%)$ and higher yield (545 kg/ha) could be best achieved with seed treatment of carbendazim @ $2 \mathrm{~g} / \mathrm{kg}+$ soil drenching with carbendazim @ $1 \mathrm{~g} / 1\left(\mathrm{~T}_{6}\right)$ followed by disease incidence $(11.2 \%)$ and yield $532 \mathrm{Kg} / \mathrm{ha}$ in the treatment $\mathrm{T}_{5}$ (seed treatment with T. viride +P.fluorescens @ 10 $\mathrm{g} / \mathrm{kg}+$ soil application of $P$. fluorescens @ $2.5 \mathrm{~kg} / \mathrm{ha}+T$. viride@ $2.5 \mathrm{~kg} / \mathrm{ha}$ enriched in $100 \mathrm{~kg}$ of FYM + neem cake @ $250 \mathrm{~kg} / \mathrm{ha}$ at sowing) during summer, 2018.The present investigation is in line with the report of Jaiman et al., (2009). With respect to grain yield, all integrated treatments recorded significantly higher seed yield than untreated check (control).

The present work indicated that seed treatment and soil drenching with fungicide (carbendazim) and seed treatment, incorporation of bioagents (enriched in yard manure and neem cake) in soil are reported a new information for the management of sesame stem and root rot disease in South Bengal condition. 


\section{References}

Chauhan, M. S. 1988. Relative efficiency of different methods for the control of seedling disease of cotton caused by Rhizoctonia bataticola. Indian J. Mycol. Pl. Pathol. 18 (1): 25-30.

Jaiman, R. K, Jain, S. C. and Sharma P. 2009. Field evaluation of fungicides, bioagents and soil amendments against root rot caused by Macrophomina phaseolina in cluster bean. J. Mycol. Pl. Pathol. 39 (1): 74-76.

Jha, G. K., Pal, S., Mathur, V. C., Bisaria, G., Dubey, S. K. 2014. Edible oilseed supply and demands scenario in India: Implication of policy, Div Agric Economics, IARI, New Delhi.

Kumar, S. and Goel, P.D. 1994. A great ancient oilseed sesamum. Farmers and Parliament. 12: 6-7.

Maiti, S., Hegde, M. R. and Chattopadhyay, S. B. 1988. Handbook of Annual Oilseed Crops. Oxford and IBH Publ. Co. Pvt. Ltd., New Delhi.

Mihail, J. D. and Taylor, S. J. 1995. Interpreting variability among isolates of Macrophomina phaseolina in pathogenicity, pycnidium production, and chlorate utilization. Can. J. Bot. 73 : 1596-1603.

Murugesan, M., Shanmugam, N., Menon, P. P. V., Arokiaraj, A., Dhamo, K. P. and Kochubabu, M. 1978. Statistical arrangement of yield loss of sesame due to insect pests and diseases. Madras Agric. J. 65: 290-295.

Paulitz, T. C. 2000. Population dynamics of biocontrol agents and pathogens in soils and rhizospheres. Eur. J. Pl. Pathol. 106: 401-413.

Shumaila, S., Khan, M. R. 2016. Management of root rot of mungbean caused by Macrophomina phaseolina through seed treatment with fungicides. Indian Phytopathol. 69 (2): 26-35.

Shyu, Y. S. and Hwang, L. S. 2002. Antioxidative activity of the crude extract of lignin glycosides from unroasted Burma black sesame meal. Int. Food Res. 35: 357-365.

Vyas, S. C. 1981. Diseases in sesamum in India and their control. Pesticides. 15:10.

Vyas, S. C., Prasad, K. V. V. and Khare, M. N. 1984. Diseases of sesamum and niger in India and their control. Department of Plant Pathology, JNKVV, Jabalpur, M. P. Bull. pp.16.

\section{How to cite this article:}

Nayan Kishor Adhikary, Md. Riton Chowdhury, Tamina Begum and Rambilash Mallick. 2019. Integrated Management of Stem and Root Rot of Sesame (Sesamum indicum L.) caused by Macrophomina phaseolina (Tassi) Goid. Int.J.Curr.Microbiol.App.Sci. 8(04): 804-808. doi: https://doi.org/10.20546/ijcmas.2019.804.089 